\title{
Wnt3a upregulates brain-derived insulin by increasing NeuroD1 via Wnt/ $\beta$-catenin signaling in the hypothalamus
}

\author{
Jaemeun Lee ${ }^{1}$, Kyungchan Kim', Seong-Woon Yu ${ }^{1}$ and Eun-Kyoung Kim²²
}

\begin{abstract}
Background: Insulin plays diverse roles in the brain. Although insulin produced by pancreatic $\beta$-cells that crosses the blood-brain barrier is a major source of brain insulin, recent studies suggest that insulin is also produced locally within the brain. However, the mechanisms underlying the production of brain-derived insulin (BDI) are not yet known.

Results: Here, we examined the effect of Wnt3a on BDI production in a hypothalamic cell line and hypothalamic tissue. In N39 hypothalamic cells, Wnt3a treatment significantly increased the expression of the Ins2 gene, which encodes the insulin isoform predominant in the mouse brain, by activating Wnt/ $\beta$-catenin signaling. The concentration of insulin was higher in culture medium of Wnt3a-treated cells than in that of untreated cells. Interestingly, neurogenic differentiation 1 (NeuroD1), a target of $\mathrm{Wnt} / \beta$-catenin signaling and one of transcription factors for insulin, was also induced by Wnt3a treatment in a time- and dose-dependent manner. In addition, the treatment of BIO, a GSK3 inhibitor, also increased the expression of Ins2 and NeuroD1. Knockdown of NeuroD1 by lentiviral shRNAs reduced the basal expression of Ins2 and suppressed Wnt3a-induced Ins2 expression. To confirm the Wnt3a-induced increase in Ins2 expression in vivo, Wnt3a was injected into the hypothalamus of mice. Wnt3a increased the expression of NeuroD1 and Ins2 in the hypothalamus in a manner similar to that observed in vitro.
\end{abstract}

Conclusion: Taken together, these results suggest that $\mathrm{BDI}$ production is regulated by the Wnt/ $\beta$-catenin/NeuroD1 pathway in the hypothalamus. Our findings will help to unravel the regulation of BDI production in the hypothalamus.

Keywords: Brain-derived insulin, Hypothalamus, Wnt/ $\beta$-catenin signaling, NeuroD1

\section{Background}

Recognition of the importance of insulin action in the brain has grown in many aspects such as energy balance, glucose homeostasis, neuronal survival, synapse formation, and cognition [1-4]. In particular, studies on the relationship between metabolic and neurodegenerative diseases emphasized the role of insulin signaling in the brain [5-10]. However, the source of insulin in the brain has not been fully investigated.

\footnotetext{
* Correspondence: ekkim@dgist.ac.kr

${ }^{1}$ Department of Brain and Cognitive Sciences, Daegu Gyeongbuk Institute of Science and Technology (DGIST), 333 Techno Jungang-daero,

Hyeonpung-myeon, Dalseong-gun, Daegu 42988, South Korea

${ }^{2}$ Neurometabolomics Research Center, Daegu Gyeongbuk Institute of

Science and Technology (DGIST), 333 Techno Jungang-daero,

Hyeonpung-myeon, Dalseong-gun, Daegu 42988, South Korea
}

Insulin produced in pancreatic $\beta$-cells is a major source of plasma insulin. Insulin produced by the pancreas is supplied to the brain from the blood circulation through the blood-brain barrier [11, 12], since insulin can be transported across this barrier [13]. However, not all insulin in the brain comes from the pancreas, because insulin can also be produced in the brain [14, 15]. Insulin mRNA is detected in various regions of the brain both during development and in adults. Rodents have two non-allelic insulin genes, Ins 1 and Ins2 $[14,15]$. In the pancreas, both genes are expressed, with Ins2 expressed at a higher level [16]. Interestingly, Ins1 mRNA is not detected in the brain. Instead, Ins 2 mRNA is found in limbic and olfactory regions, hippocampus, and hypothalamus [6, 17-22]. Nevertheless, it is difficult to detect Ins2 mRNA in the brain because of its quite low expression level. Using single-cell digital PCR, one research group found that the 
neurogliaform cells in the cerebral cortex express Ins2 mRNA [23]. To verify the production of insulin in the brain, brain was stained with antibodies against connecting peptide (c-peptide), byproduct of proinsulin processing. C-peptide-positive signal was found in the central nervous system, and the pattern of c-peptide staining showed correlation with that of Ins 2 expression [24, 25]. However, the mechanisms of local production of insulin in the brain, which is called brain-derived insulin (BDI), and its roles remain unclear.

Wnt signaling is involved in brain development [26-28]. Wnt proteins are a diverse family of secreted glycoproteins that act as ligands for receptor-mediated signaling pathways [29]. The three well-characterized Wnt signaling pathways are the canonical Wnt pathway, the non-canonical planar cell polarity pathway, and the non-canonical Wnt/calcium pathway.

The canonical Wnt signaling regulates the expression of insulin in pancreatic $\beta$-cells and the development of the pancreas [30-35]. Without Wnt ligands, $\beta$-catenin, which enhances the expression of many genes in the nucleus, is degraded by the $\beta$-catenin destruction complex [36]. Glycogen synthase kinase 3 (GSK3), a key component of the $\beta$-catenin destruction complex, phosphorylates $\beta$-catenin at Ser33, Ser37, and Thr41, leading to its degradation by the proteasome [37]. When Wnt ligands bind to Frizzled $(\mathrm{Fz})$ receptor and its coreceptor, low density lipoprotein receptor-related protein (LRP), the $\beta$-catenin destruction complex is disrupted by GSK3 inactivation [38]. Consequently, $\beta$-catenin accumulates in the cytosol and translocates into the nucleus to enhance the expression of many target genes [39].

The activity of the canonical Wnt signaling is also observed in the adult mice hypothalamus [40, 41]. Wntresponsive cells are abundant in the paraventricular and arcuate nuclei of the hypothalamus [42, 43]. In the mouse models of metabolic diseases such as diet-induced obese (DIO) mouse model and leptin-deficient $(o b / o b)$ mouse model, hypothalamic Wnt signaling is disrupted [44]. GSK3 is increased in the hypothalamus of DIO mice, and a GSK3 inhibitor acutely improves glucose metabolism in these mice [44]. In addition, the phosphorylated (active) form of LRP is down-regulated in $o b / o b$ mice [45]. Downregulated Wnt signaling is reinstated by leptin treatment [45]. These reports suggest that Wnt signaling is necessary for glucose homeostasis in the hypothalamus. However, the specific mechanism how Wnt signaling modulates metabolism in the hypothalamus has not yet been revealed.

Insulin signaling plays many roles in the brain [46], however, the mechanisms underlying the expression of insulin in the brain have not been discovered yet. In this study, we examined how Wnt signaling regulates the production of insulin in the hypothalamus. The results of our research will help to reveal the mechanisms underlying the regulation of $\mathrm{BDI}$ production in the hypothalamus.

\section{Results \\ Wnt3a increases the levels of Ins2 mRNA and protein in N39 cells}

We used the immortalized mouse hypothalamic neuronal cell line N39 (mHypoE-39) to investigate the mechanism of BDI production, because N39 cells express Ins2 [14]. Consistent with the previous findings [14], Ins2 mRNA but not Ins 1 mRNA was detected by quantitative realtime PCR (qRT-PCR) in N39 cells (data not shown). Wnt3a increases insulin expression in pancreatic $\beta$-cells and neuronal progenitor cells (derived from adult hippocampus or the olfactory bulb) via Wnt/ $\beta$-catenin signaling $[35,47]$. Therefore, we tested whether Wnt3a can induce insulin production in N39 cells.

N39 cells were treated with Wnt3a (25 or $100 \mathrm{ng} / \mathrm{mL}$ ) for 6,12 , or $24 \mathrm{~h}$. After Wnt3a treatment for $6 \mathrm{~h}$, the Ins 2 mRNA level increased significantly (by 4.1-fold at $25 \mathrm{ng} / \mathrm{mL}$ and 3.5 -fold at $100 \mathrm{ng} / \mathrm{mL}$ Wnt3a; Fig. 1a), although this increase was not dose-dependent. After $12 \mathrm{~h}$, Wnt3a increased the Ins 2 mRNA level by 3.9 -fold at $25 \mathrm{ng} / \mathrm{mL}$ and 4.7 -fold at $100 \mathrm{ng} / \mathrm{mL}$. After $24 \mathrm{~h}$, the Ins $2 \mathrm{mRNA}$ level was increased by 5.4 -fold at $25 \mathrm{ng} / \mathrm{mL}$ and 6.8-fold at $100 \mathrm{ng} / \mathrm{mL}$ of Wnt3a compared to vehicletreated cells. Thus, the Ins 2 mRNA levels were significantly increased in Wnt3a-treated N39 cells in a time-dependent manner at 12 and $24 \mathrm{~h}$.

To confirm the expression of insulin, we checked its protein level using immunofluorescence analysis with an antibody against proinsulin and found stronger proinsulin-positive signals in N39 cells treated with Wnt3a $(100 \mathrm{ng} / \mathrm{mL})$ for $24 \mathrm{~h}$ than in vehicle-treated cells (Fig. 1b).

To further verify the production of insulin in Wnt3atreated N39 cells, culture medium was collected after Wnt3a treatment for $24 \mathrm{~h}$, concentrated, and the concentration of immuno-reactive insulin was measured with ELISA. The concentration of insulin in culture medium was significantly increased (by $17.4 \%$ ) in cells treated with Wnt3a (100 ng/mL) as compared to vehicle-treated cells (Fig. 1c).

Taken together, our results indicate that Wnt3a increases the levels of insulin mRNA and protein in N39 cells. Furthermore, Wnt3a also increases secretion of insulin from N39 cells.

\section{Wnt3a induces insulin production in N39 cells through the canonical Wnt/ $\beta$-catenin signaling}

In the canonical Wnt signaling, Wnt ligands bind to $\mathrm{Fz}$ receptor and LRP, and this binding results in the stabilization, accumulation, and nuclear translocation of $\beta$-catenin $[48,49]$. To determine whether Wnt3a 


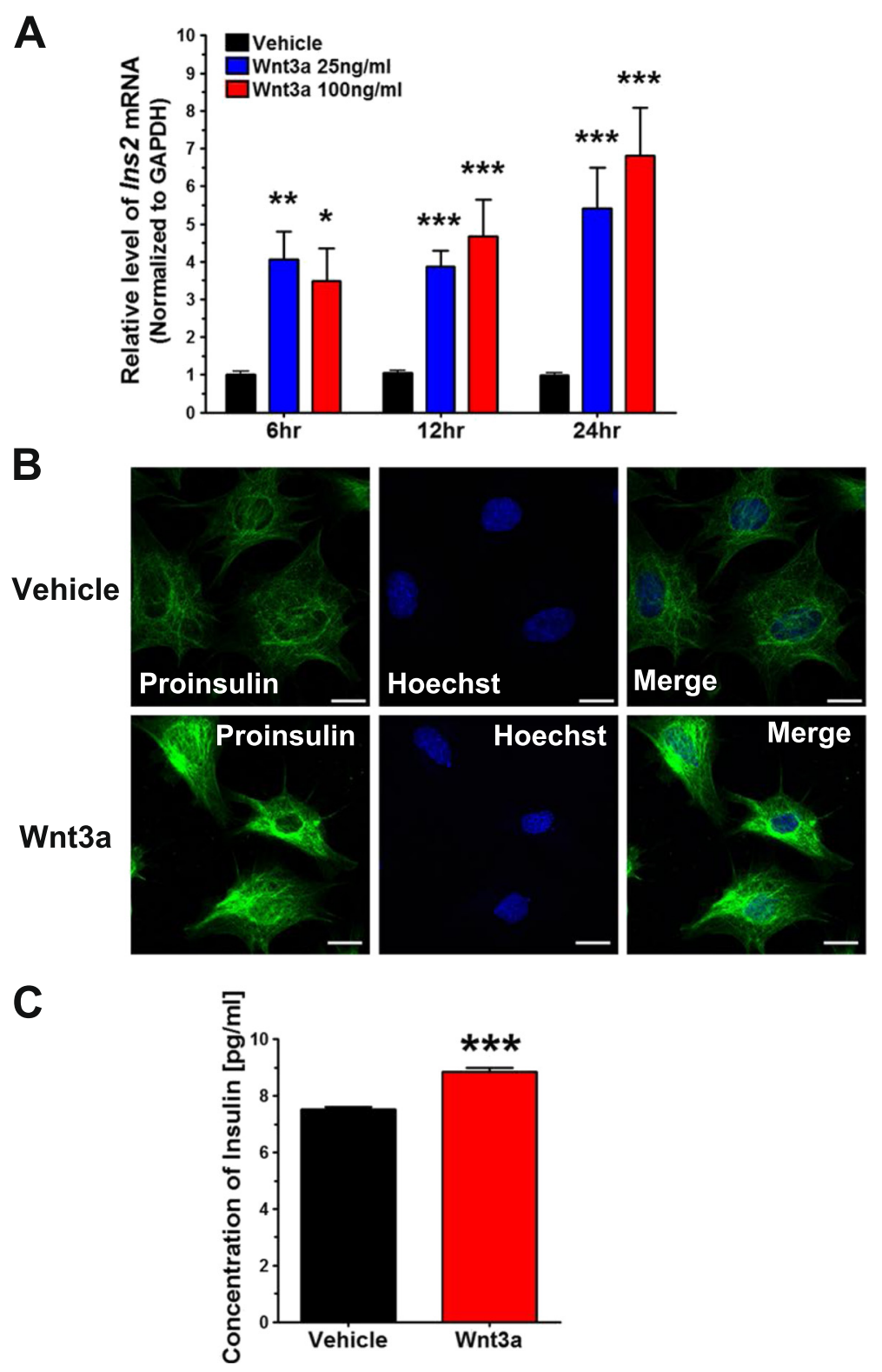

Fig. 1 Wnt3a upregulates insulin synthesis and secretion from N39, a hypothalamic neuronal cell line. a N39 cells were treated with vehicle (PBS) or Wnt3a (25 or $100 \mathrm{ng} / \mathrm{mL}$ ) for 6, 12, and $24 \mathrm{~h}$, and the levels of Ins2 mRNA were measured by qRT-PCR and normalized to the levels of GAPDH mRNA $(n=23)$. b N39 cells were treated with vehicle or Wnt3a $(100 \mathrm{ng} / \mathrm{mL})$ for $24 \mathrm{~h}$, and the induction of insulin was examined by immunofluorescence analysis with an antibody against proinsulin. Nuclei were stained with Hoechst 33342 dye. Scale bar, $20 \mu \mathrm{m}$. c Culture media were collected for $24 \mathrm{~h}$ after treatment with vehicle or Wnt3a (100 ng/mL), concentrated in Vivaspin columns, and insulin concentrations were measured by ELISA $(n=6)$. Data are means + SEM. ${ }^{*} p<0.05,{ }^{* *} p<0.01,{ }^{* * *} p<0.001$ compared with vehicle control at each time point

induced Ins2 through the canonical Wnt signaling, we measured the level of $\beta$-catenin in Wnt3a-treated N39 cells.

Immunoblot analysis (Fig. 2a-c) showed that Wnt3a strongly stabilized $\beta$-catenin in a dose-dependent manner, as shown by a significant increase in the levels of active $\beta$-catenin, in which the Ser33, Ser37, and Thr41 residues are dephosphorylated. Consequently, total $\beta$ catenin also accumulated in a dose-dependent manner.
Consistent with the immunoblotting data, immunofluorescence analysis showed that Wnt3a treatment resulted in the accumulation of active $\beta$-catenin (Fig. 2d). Furthermore, active $\beta$-catenin was clearly co-localized with Hoechst 33342, a nuclear marker, in Wnt3a-treated N39 cells.

To ascertain the role of GSK3 in insulin production stimulated by Wnt3a treatment in N39 cells, we treated them with 6-bromoindirubin-3'-oxime (BIO), a specific 
A

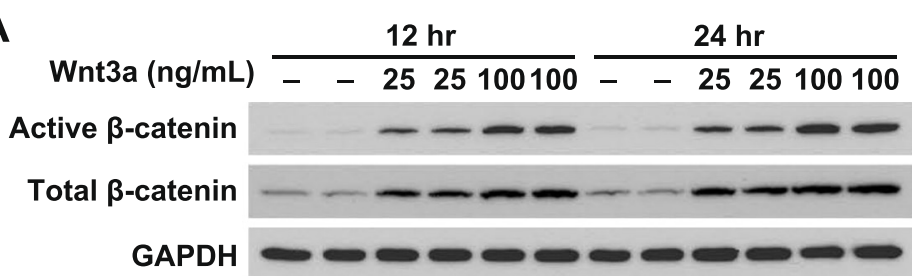

B

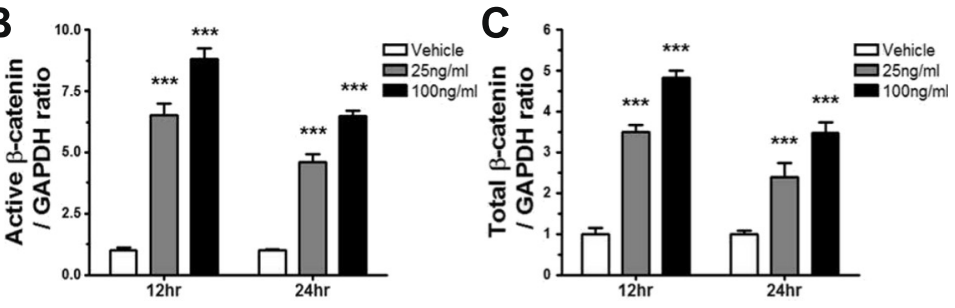

D
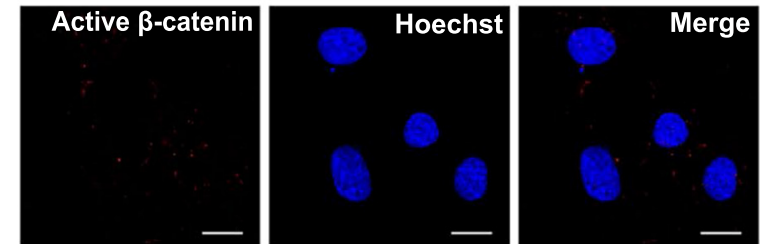

Vehicle

Wnt3a
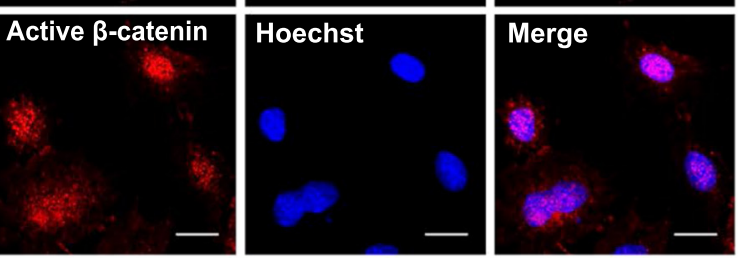

E

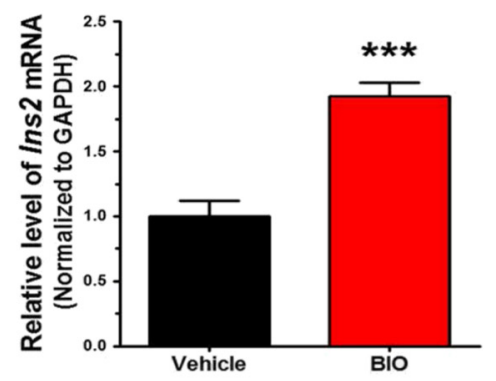

F

$$
\text { BIO (1 } \mu \mathrm{M}) \text { Ctrl } 1 \mathrm{hr} 3 \mathrm{hr} 6 \mathrm{hr} 12 \mathrm{hr}
$$

Active $\beta$-catenin

Total $\beta$-catenin

GAPDH

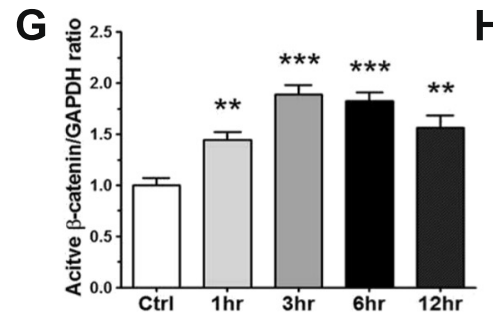

H

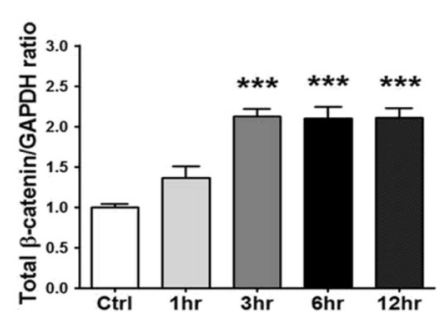

Fig. 2 (See legend on next page.) 
(See figure on previous page.)

Fig. 2 Wnt3a induces the expression of Ins2 by activating Wnt/ $\beta$-catenin signaling. a N39 cells were treated with vehicle or Wnt3a ( $25 \mathrm{or} 100 \mathrm{ng} / \mathrm{mL})$ for 12 and 24 h. Active (Non-phospho) $\beta$-catenin and total $\beta$-catenin were detected using immunoblot assay. $\mathbf{b}$ and $\mathbf{c}$ The intensity of bands shown in (a) was quantified by using the ImageJ software with normalization to GAPDH $(n=6)$. $\mathbf{d}$ N39 cells were treated with vehicle or Wnt3a $(100 \mathrm{ng} / \mathrm{mL})$ for $24 \mathrm{~h}$, and active $\beta$-catenin was examined by immunofluorescence analysis; Hoechst 33342 dye was used for nuclear staining. Scale bar, $20 \mu \mathrm{m}$. e N39 cells were treated with $1 \mu \mathrm{M} \mathrm{BIO}$, a GSK3 inhibitor, for $12 \mathrm{~h}$, and the level of Ins2 mRNA was measured by qRT-PCR $(n=9)$. $\mathbf{f}$ N39 cells were treated with vehicle (DMSO) or $1 \mu \mathrm{M} \mathrm{BIO} \mathrm{for} 1,3,6$, and $12 \mathrm{~h}$ to observe accumulation of active $\beta$-catenin and total $\beta$-catenin $(n=6) . \mathbf{g}$ and $\mathbf{h}$ Quantification of immunoblot data in $(\mathbf{f})$ using the ImageJ software was performed with normalization to GAPDH. Data are means + SEM. ${ }^{* *} p<0.01,{ }^{* * *} p<0.001$ compared with vehicle treatment

GSK3 inhibitor. BIO inhibits GSK3 by interacting with its ATP binding pocket, leading to activation of the canonical Wnt signaling in human and mouse embryonic stem cells [50, 51]. BIO treatment increased the level of Ins 2 mRNA by 2 -fold after treatment for $12 \mathrm{~h}$ (Fig. 2e). As expected, the levels of both active and total $\beta$-catenin increased by up to 2-fold after BIO treatment for $3 \mathrm{~h}$, and the increased level was maintained after BIO treatment for 6 and $12 \mathrm{~h}$ (Fig. 2f-h). The induction of Ins 2 and accumulation of $\beta$-catenin upon BIO treatment showed trends similar to those of the effects of Wnt3a treatment. Collectively, these data indicate that Wnt3a increases insulin production by activating $\beta$-catenin and it might be mediated by inactivation of GSK3.

\section{Induction of insulin production by Wnt3a depends on NeuroD1}

To unravel the mechanism of insulin production in N39 cells, we investigated the downstream targets of Wnt/ $\beta$-catenin signaling. Among many targets of this pathway, we tested NeuroD1, which is known as a candidate transcription factor involved in the expression of the insulin genes in the pancreas [52].

We measured the NeuroD1 mRNA level at 6, 12, and $24 \mathrm{~h}$ in N39 cells treated with Wnt3a (25 or $100 \mathrm{ng} / \mathrm{mL}$ ). At $6 \mathrm{~h}$, the level of NeuroD1 mRNA was significantly increased in comparison with vehicle-treated N39 (by 3.7 -fold at $25 \mathrm{ng} / \mathrm{mL}$ and 3.5-fold at $100 \mathrm{ng} / \mathrm{mL}$ Wnt3a; Fig. 3a). At 12 h, NeuroD1 mRNA was upregulated by

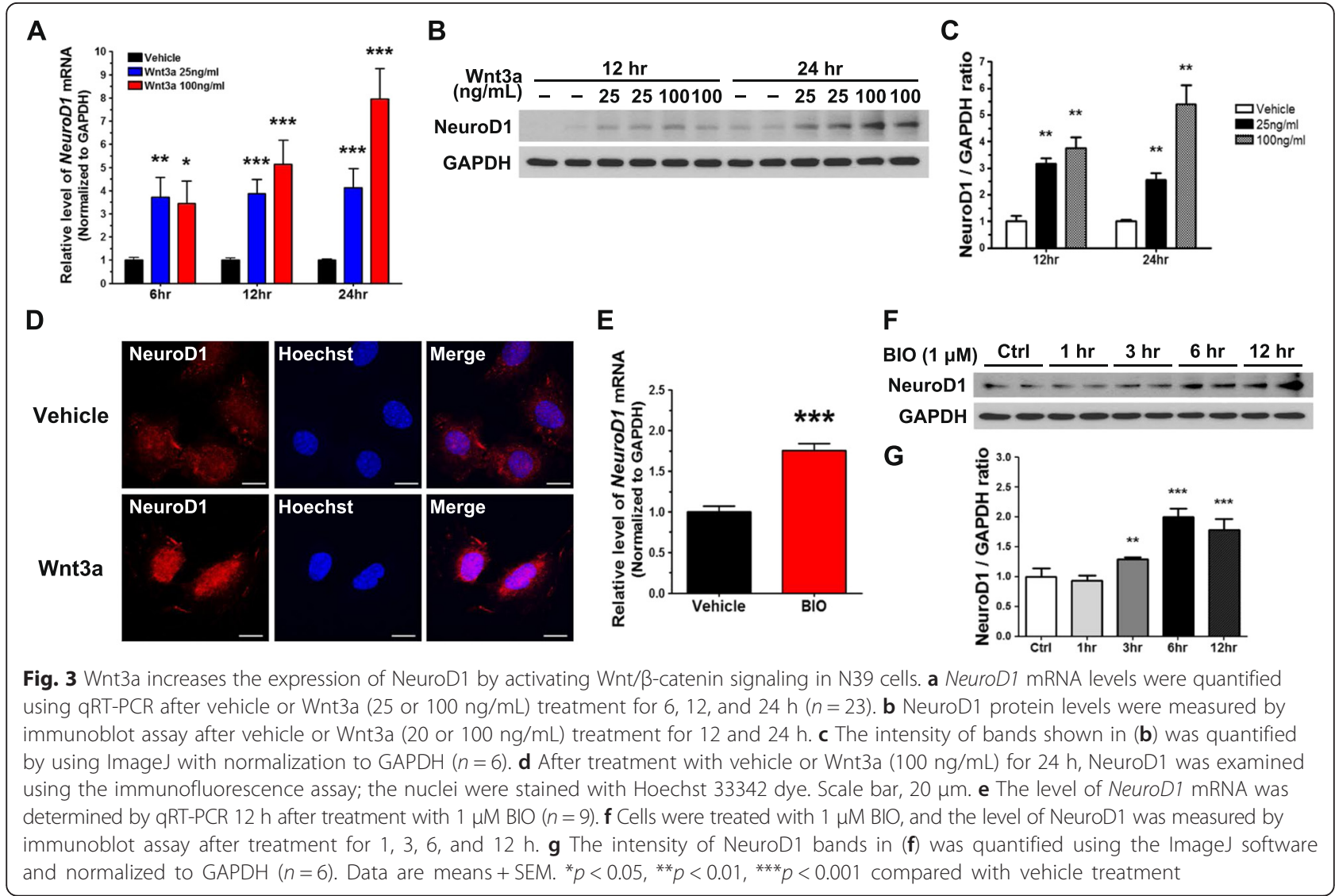


3.9-fold at $25 \mathrm{ng} / \mathrm{mL}$ and 5.1 -fold at $100 \mathrm{ng} / \mathrm{mL}$ Wnt3a. At $24 \mathrm{~h}$, the effects on NeuroD1 mRNA were even more profound (4.1-fold increase at $25 \mathrm{ng} / \mathrm{mL}$ and 8.0-fold increase at $100 \mathrm{ng} / \mathrm{mL}$ Wnt3a). The induction of NeuroD1 mRNA by Wnt3a showed a pattern similar to that of Ins2 mRNA: after Wnt3a treatment for $6 \mathrm{~h}$, Ins 2 and NeuroD1 did not show dose-dependent effects, whereas both the Ins2 and NeuroD1 mRNA levels were significantly increased in a dose-dependent manner at 12 and $24 \mathrm{~h}$. Interestingly, at $1.5 \mathrm{~h}$ after Wnt3a $(100 \mathrm{ng} / \mathrm{mL})$ treatment, the mRNA level of NeuroD1 was increased significantly whereas that of Ins2 was not increased yet (Additional file 1: Figure S1A and S1B). To validate the effect of Wnt3a on NeuroD1 expression, we determined the level of the NeuroD1 protein in Wnt3a-treated N39 cells by immunoblotting (Fig. $3 \mathrm{~b}$ and c). At $12 \mathrm{~h}$, the NeuroD1 level was significantly increased (by 3.2 fold at $25 \mathrm{ng} / \mathrm{mL}$ and 3.8 fold at $100 \mathrm{ng} / \mathrm{mL}$ Wnt3a). At $24 \mathrm{~h}$, the increase was dose-dependent ( 2.6 fold at $25 \mathrm{ng} / \mathrm{mL}$ and 5.4 fold at $100 \mathrm{ng} / \mathrm{mL} \mathrm{Wnt3a).}$

NeuroD1 was detectable in N39 cells by immunofluorescence analysis (Fig. 3d). When the cells were treated with Wnt3a $(100 \mathrm{ng} / \mathrm{mL})$ for $24 \mathrm{~h}$, the intensity of the NeuroD1-positive signal was apparently greater. Colocalized with Hoechst 33342 demonstrated Wnt3ainduced nuclear localization of NeuroD1. These data demonstrate that Wnt3a increases both the expression of NeuroD1 and its translocation into the nucleus in N39 cells.

We also treated N39 cells with BIO to determine whether the induction of NeuroD1 is mediated by GSK3dependent Wnt/B-catenin signaling. The level of NeuroD1 mRNA was increased by 2 -fold in cells treated with BIO for $12 \mathrm{~h}$ (Fig. 3e). In a similar manner, BIO treatment for 3,6 , or 12 h significantly increased the levels of the NeuroD1 protein (by up to 2-fold compared to vehicle-treated N39 cells; Fig. 3f and g). These results suggest that Wnt/ $\beta$-catenin signaling increases the expression of NeuroD1 through GSK3 inhibition.

To determine whether the induction of BDI by Wnt3a is NeuroD1-dependent, knockdown experiments were designed using a lentiviral vector system. Among 5 candidate short-hairpin RNA (shRNA) constructs designed to target NeuroD1, two shRNAs were chosen because of their high knockdown efficiency and used in combination for NeuroD1 knockdown (data not shown). Lentiviruses expressing NeuroD1 shRNAs significantly suppressed the expression of NeuroD1: by $80 \%$ at the mRNA level (Fig. 4a) and by $50 \%$ at the protein level after $72 \mathrm{~h}$ infection (Fig. 4b and c) compared to lentivirus expressing non-targeting shRNA. Interestingly, NeuroD1 knockdown reduced the expression of Ins 2 by $40 \%$ of that in non-targeting shRNA lentivirus-infected cells in the absence of Wnt3a, indicating that NeuroD1 is

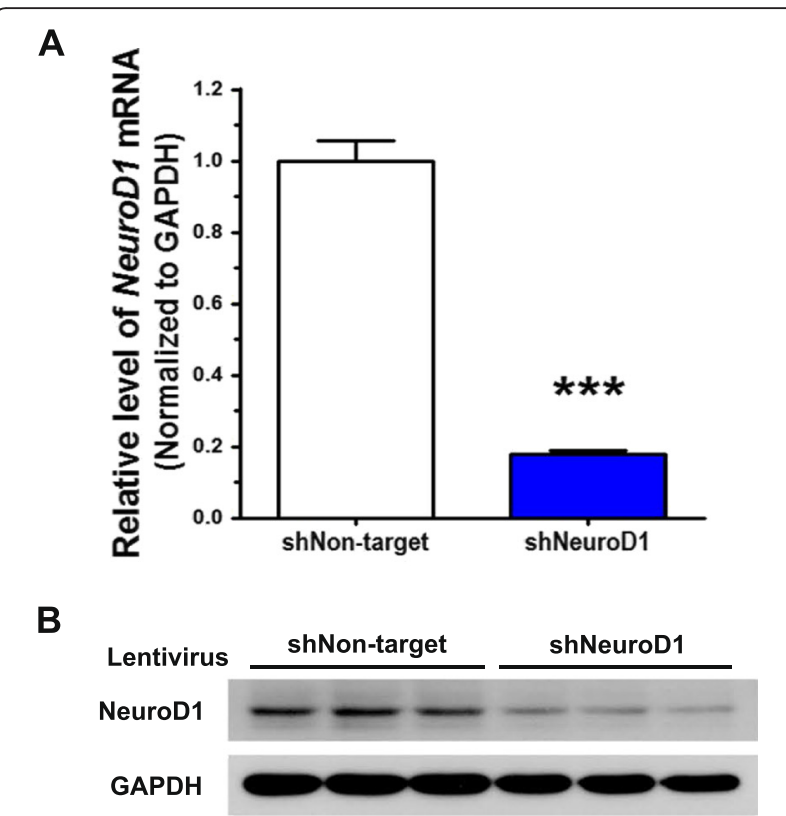

C

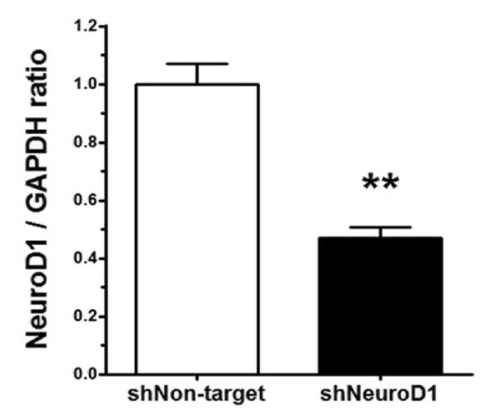

D

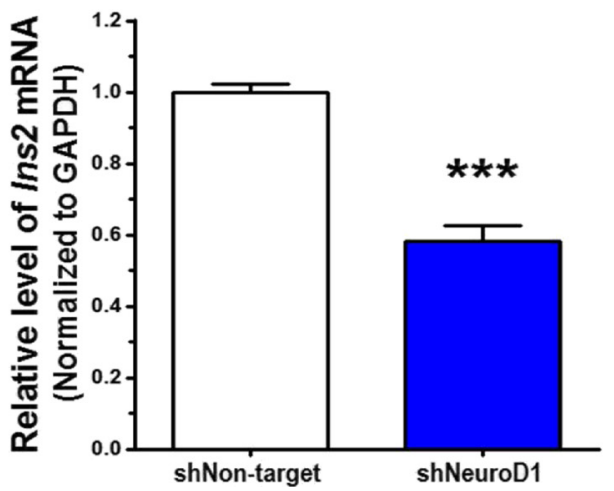

Fig. 4 Knockdown of NeuroD1 reduces the expression of Ins2. NeuroD1 was knocked down by infecting N39 cells with lentivirus containing shRNA (shNeuroD1) for 72 h. a Knockdown efficiency was determined by examining the levels of NeuroD1 mRNA using qRT-PCR $(n=23)$. $\mathbf{b}$ The level of NeuroD1 protein was assessed by immunoblot assay, and $\mathbf{c}$ the intensity of NeuroD1 bands was quantified using the ImageJ software with normalization to GAPDH $(n=6)$. $\mathbf{d}$ The basal expression of Ins 2 was determined by qRT-PCR after infection with shRNA lentivirus against NeuroD1 for $72 \mathrm{~h}$ $(n=12)$. Data are means + SEM. ${ }^{* *} p<0.01,{ }^{* * *} p<0.001$ compared with non-targeting shRNA lentivirus-infected cells (shNon-target) 
involved in maintaining the expression of Ins 2 in the basal state (Fig. 4d).

In addition, we treated N39 cells, in which NeuroD1 was knocked down, with Wnt3a (100 ng/mL) to examine any changes in the induction of Ins2. As shown in Fig. 5a and $b, W n t 3 a$ treatment resulted in the accumulation of active and total $\beta$-catenin in cells infected with lentiviruses expressing either non-targeting shRNA or NeuroD1 shRNA. However, as demonstrated by using qRT-PCR, the NeuroD1 transcript was not upregulated by Wnt3a in N39 cells with knocked down NeuroD1, although it was significantly increased in non-targeting shRNA lentivirus-infected N39 cells (Fig. 5c). Furthermore, Wnt3a treatment failed to induce Ins 2 in N39 cells with knocked down NeuroD1 whereas Wnt3a significantly increased the level of Ins 2 mRNA in non-targeting shRNA lentivirus-infected N39 cells (Fig. 5d).

Taken together, these results suggest that NeuroD1 is a key transcription factor for Wnt3a-induced Ins2 expression through Wnt/ $\beta$-catenin signaling in N39 cells.

\section{Wnt3a administration induces the expression of Ins2 and NeuroD1 in the hypothalamus}

Many reports showed Wnt activity in the adult hypothalamus [40-43]. Autocrine and/or paracrine Wnt ligands may be responsible for Wnt activity in the hypothalamus. To test Wnt3a-induced BDI production in the hypothalamus in vivo, we first measured the mRNA level of Wnt3a by qRT-PCR in the hypothalamic tissues (Fig. 6a). Although the amount of Wnt $3 a$ mRNA was relatively lower than that of Ins 2 , the expression of $W n t 3 a$ was detected in the hypothalamus.

To examine the effect of Wnt3a treatment on the synthesis of Ins 2 mRNA in hypothalamic tissue, we introduced Wnt3a into the hypothalamus by intracerebroventricular (icv) injection and collected hypothalamic tissues for analysis $24 \mathrm{~h}$ after injection. Administration of Wnt3a (4 or $20 \mathrm{ng})$ significantly increased the levels of Ins 2 mRNA (by 1.3-fold and 1.6-fold, respectively; Fig. 6b). Interestingly, the levels of NeuroD1 mRNA were also upregulated (Fig. 6c). These results indicate that Wnt3a increases the expression of Ins 2 and NeuroD1 in the hypothalamus.

\section{Discussion}

Despite accumulating evidence about BDI, the specific mechanism of BDI production is not yet well understood. In particular, hypothalamic insulin production has not been reported. Considering that the hypothalamus has a large number of neurosecretory cells, which produce and secrete diverse neuropeptides involved in maintaining homeostasis, it is plausible that BDI plays a specific role in maintaining energy homeostasis and regulating metabolism in the hypothalamus. In this study, we demonstrated that Wnt3a increases insulin production in the

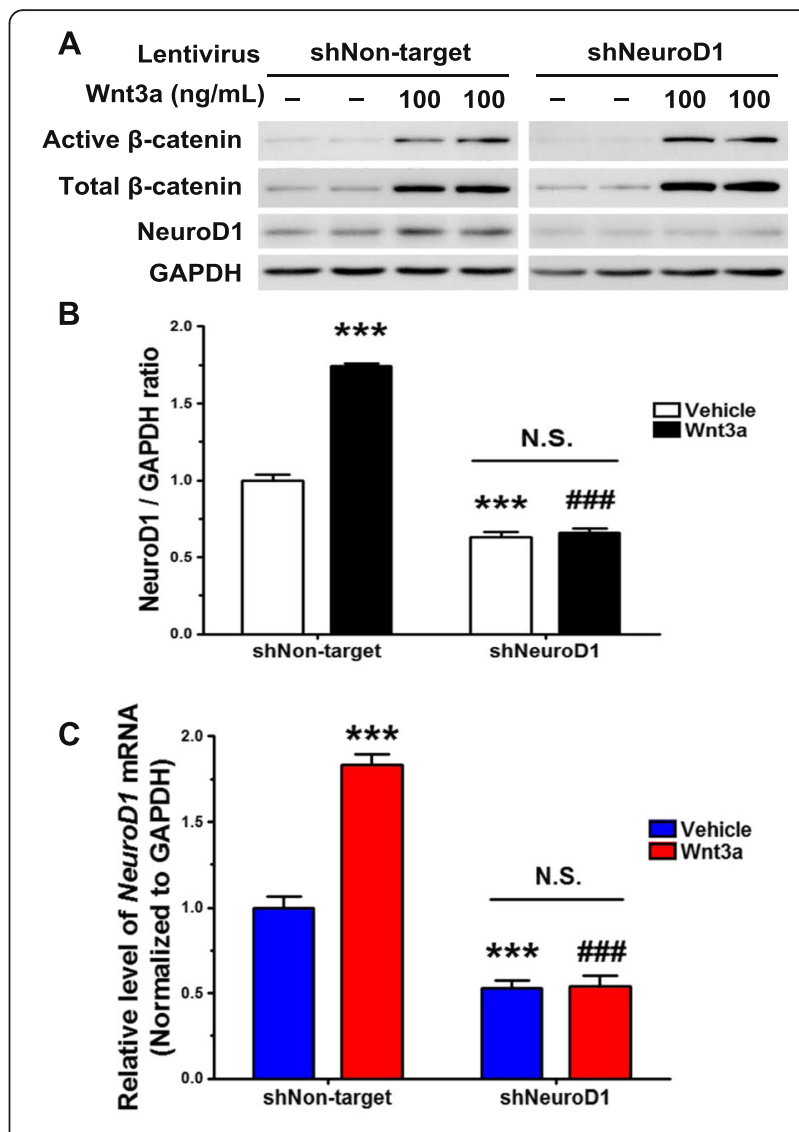

D

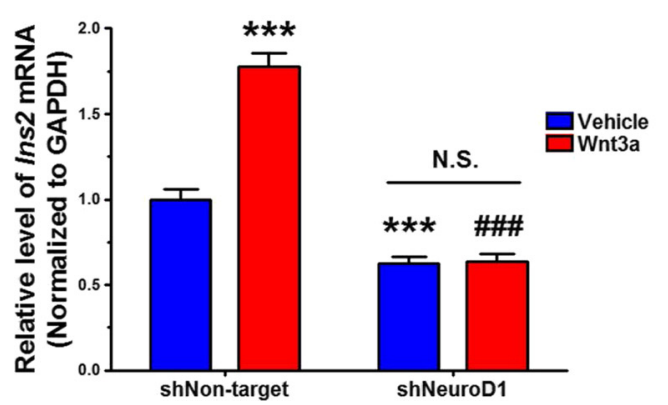

Fig. 5 Wnt3a-induced Ins2 upregulation is blocked by knockdown of NeuroD1. NeuroD1 was knocked down by infecting N39 cells with lentivirus containing shRNA for $72 \mathrm{~h}$. a N39 cells were infected by lentiviral shRNA against NeuroD1 for $48 \mathrm{~h}$ and then treated with Wnt3a $(100 \mathrm{ng} / \mathrm{mL})$ for $24 \mathrm{~h}$. The levels of active and total $\beta$-catenin and NeuroD1 protein were determined by immunoblot assay. $\mathbf{b}$ The intensity of NeuroD1 signal in (a) was quantified using the Image J software $(n=4)$. The levels of NeuroD1 mRNA (c) and Ins2 mRNA (d) were measured by qRT-PCR in N39 cells that were infected with lentiviral non-targeting or NeuroD1 shRNA for $48 \mathrm{~h}$ and then treated with Wnt3a $(100 \mathrm{ng} / \mathrm{mL})$ for $24 \mathrm{~h}(n=9)$. Data are means + SEM. ${ }^{* * *} p<0.001$ compared with vehicle treatment in shNon-target. $\# \# \# p<0.001$ compared with Wnt3a treatment in shNon-target. N.S., not significant within shNeuroD1 samples

hypothalamus by activating $\mathrm{Wnt} / \beta$-catenin signaling and NeuroD1 induction. Inhibition of GSK3, which phosphorylates $\beta$-catenin and thus promotes its degradation, leads 


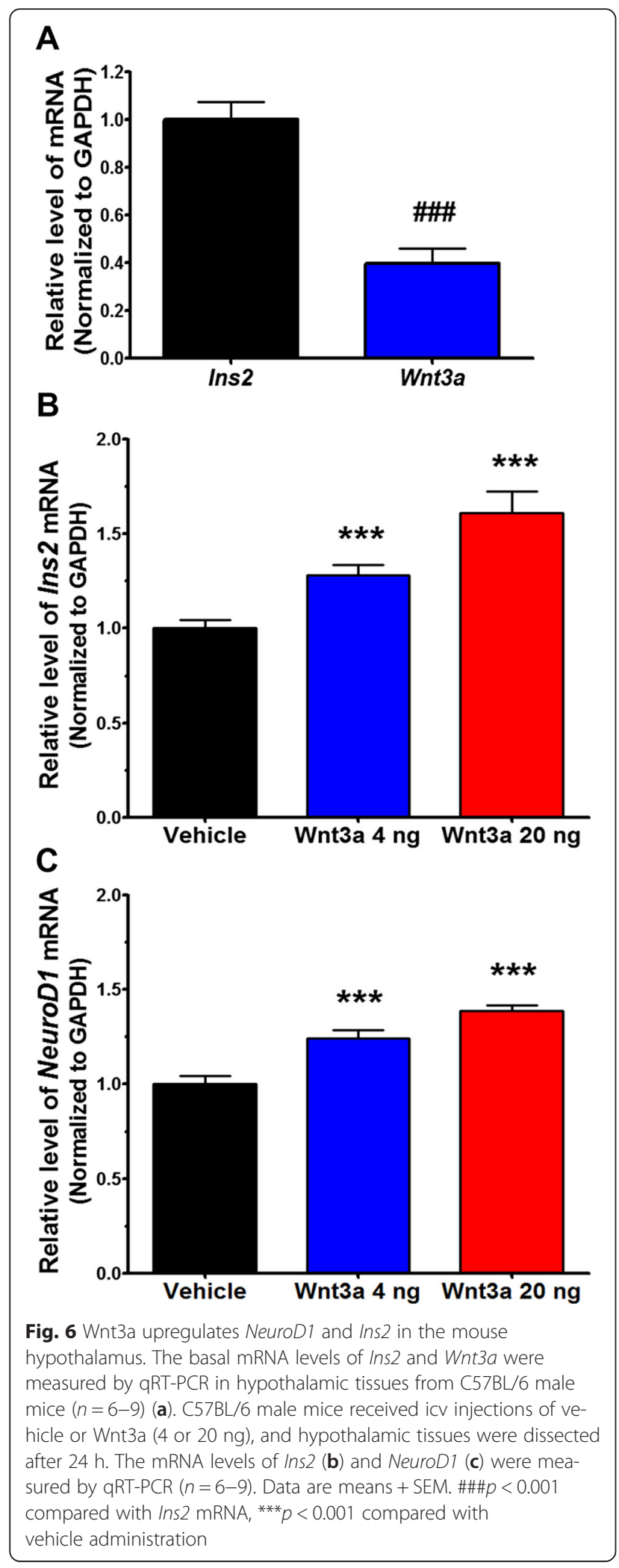

to accumulation of $\beta$-catenin in the cytosol. Accumulated $\beta$-catenin translocates into the nucleus, where it enhances the expression of NeuroD1 with T-cell factor (TCF).
Synthesized NeuroD1 also moves into the nucleus and induces insulin production (Fig. 7).

Hippocampus and olfactory regions are known as brain regions that express insulin higher than other brain regions [15, 35]. The Ins $2 \mathrm{mRNA}$ level is lower in the hypothalamus than in the hippocampus [14, 17]. However, insulin signaling plays important roles in controlling food intake, glucose metabolism, and energy expenditure in the hypothalamus [53, 54]. Nevertheless the expression level is lower than other regions, we hypothesized that BDI synthesized in the hypothalamus could regulate metabolism by acting on the hypothalamic neurocircuits.

The activation of $\mathrm{Wnt} / \beta$-catenin signaling enhances the transcription of downstream genes via the formation of a complex between active $\beta$-catenin and TCF [55]. Our results demonstrate not only the accumulation of active and total $\beta$ catenin (Fig. 2a-c), but also the translocation of active $\beta$ catenin into the nucleus induced by Wnt3a in N39 cells (Fig. 2d). Although we did not examine the activity of the TCF complex, these results indicate activation of Wnt/ $\mathrm{B}$ catenin signaling in these cells. The level of NeuroD1, a downstream target of $\mathrm{Wnt} / \beta$-catenin signaling, was increased in Wnt3a-treated N39 cells (Fig. 3a-d). This increase in NeuroD1 expression supports that Wnt3ainduced accumulation of active $\beta$-catenin enhances the transcription of NeuroD1 gene.

To determine whether GSK3 is involved in Wnt3ainduced Ins 2 upregulation, we treated BIO to inhibit GSK3 (Fig. 2e-h, Fig. 3e-g). BIO treatment resulted in accumulation of $\beta$-catenin, and increases in the expression of NeuroD1 and Ins2, suggesting that GSK3 plays a role in the upregulation of Ins 2 by Wnt/ $\beta$-catenin signaling. The phosphorylation of GSK3 at Ser9 residue is one of mechanisms for GSK3 inactivation $[56,57]$. However, we could not observe any changes in the level of phospho-GSK3 (Ser9) when N39 was treated with Wnt3a (data not shown). Therefore, it is likely that GSK3 inhibition by Wnt3a is mediated by not phosphorylation of Ser9 but other mechanisms in our study.

NeuroD1 is a basic helix-loop-helix transcription factor that plays a role in facilitating differentiation of neurons $[58,59]$, and its gene is a target of $\mathrm{Wnt} / \beta$-catenin signaling in the brain $[52,60]$. NeuroD1 also binds to the insulin promoter to increase the expression [61, 62]. Although an increase in Ins2 mRNA levels in Wnt3a-injected hypothalamic tissues was smaller than that in N39 cells, the levels of both NeuroD1 and Ins 2 mRNAs increased in the hypothalamus of Wnt3a-injected mice. Taken together, it is likely that insulin production induced by Wnt3a, which is well known to occur in the pancreas, is conserved in the hypothalamus.

The mechanism of insulin secretion in neurons is not yet revealed. Mechanistic studies on insulin secretion in vivo are challenging, because it is difficult to pinpoint 


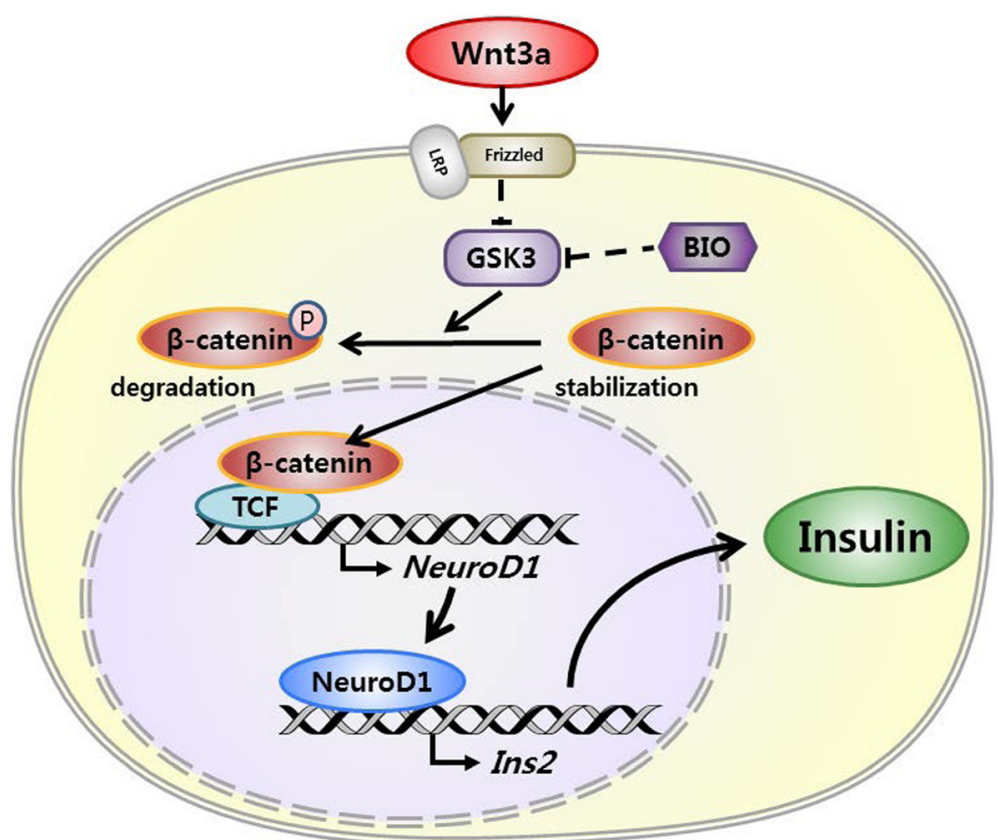

Fig. 7 The proposed regulatory mechanism of insulin expression by the Wnt/ $\beta$-catenin/NeuroD1 pathway in the hypothalamus. Wnt3a might bind to LRP and Frizzed receptor to activate the canonical Wnt pathway. GSK3 phosphorylates $\beta$-catenin and induces its degradation; Wnt3a inhibits GSK3, leading to $\beta$-catenin accumulation. Accumulated $\beta$-catenin translocates into the nucleus and enhances the expression of NeuroD1 with TCF. Up-regulated NeuroD1 also translocates into the nucleus, where it induces the production of insulin

the origin of insulin in the brain; the confounding factor is that insulin produced in the pancreas is delivered by blood circulation to the brain in vivo. Furthermore, the basal expression of insulin is not high enough to study the mechanism of its secretion in in vitro systems. Insulin-overexpressing N39 cells as an in vitro model might be useful to investigate the mechanism of insulin secretion in the future studies.

The neuron-specific insulin receptor knockout (NIRKO) mice resulted in increased food intake and moderate dietinduced obesity, demonstrating the anti-obesity role of insulin [2]. However, insulin receptor (IR) knockout mice specifically deleted in agouti-related peptide (AgRP)or pro-opiomelanocortin (POMC)-expressing neuron did not show a significant difference in energy homeostasis, especially food intake [63]. Moreover, deletion of IR in steroidogenic factor 1 (SF1)-expressing neurons of the ventromedial hypothalamus had no effect on body weight and food intake [64]. The different phenotypes among mice models suggest that the roles of insulin through IR in the brain are diverse in a cell-type specific manner. Therefore, it might be important to identify the subpopulation of hypothalamic neurons that specifically express $\mathrm{BDI}$ in order to investigate the role of BDI in the future study. It would be interesting to investigate whether Wnt3a-induced insulin production from the specific neurons in the hypothalamus can regulate the food intake and protect from obesity.

\section{Conclusions}

We demonstrate that BDI is regulated by Wnt/ $\beta$-catenin signaling in the hypothalamus. It is possible that insulin production in the hypothalamus or other brain areas changes in metabolic diseases. Further studies focused on the regulation of BDI production in the disease models with disrupted hypothalamic Wnt/ $\beta$-catenin signaling will be needed to elucidate the pathophysiological roles of BDI.

\section{Methods \\ Cell culture and treatments}

Immortalized mouse hypothalamic cell line N39 (mHypoE39) was obtained from CELLutions Biosystems and maintained in Dulbecco's modified Eagle medium (DMEM) (Sigma) supplemented with $10 \%$ fetal bovine serum (FBS) (Hyclone Laboratories) and $1 \%$ penicillin/streptomycin (GIBCO). Lenti-X ${ }^{\mathrm{mm}} 293 \mathrm{~T}$ cell line was purchased from Clontech and cultured in DMEM supplemented with $10 \%$ FBS and $1 \%$ penicillin/streptomycin. Recombinant mouse Wnt3a (1324-WN, R\&D Systems) was dissolved in phosphate-buffered saline (PBS) containing $0.2 \%$ BSA. BIO (Sigma), a specific GSK3 inhibitor, was dissolved in dimethyl sulfoxide (DMSO) at $1 \mathrm{mM}$ concentration.

\section{Animals}

Animal studies were performed in accordance with the guidelines on care and use as approved by the DGIST 
Institutional Animal Care and Use Committee. C57BL/6 mice were obtained from Koatech; 8-week-old males were used for experiments. Mice were housed in groups of 3-5 under a 12/12 h light/dark cycle (lights on from 6:00 to $18: 00)$ in an individually ventilated cage Innorack (Innovive).

\section{Administration of Wnt3a and preparation of brain tissues} Wnt3a was introduced into the hypothalamus by icv injection of $2 \mu \mathrm{L}$ of PBS containing Wnt3a (4 or $20 \mathrm{ng}$ ) into the third ventricles. Mice were euthanized with $\mathrm{CO}_{2}$ gas supplied for 3-5 min $24 \mathrm{~h}$ after Wnt3a administration. Brain was quickly removed, placed on ice, and the hypothalamus was dissected using as landmarks the optic chiasm and the mammillary bodies to depth of $\sim 2 \mathrm{~mm}$ [65]. Hypothalamic tissues were frozen in liquid nitrogen and ground mechanically on dry ice.

\section{RNA extraction and gene expression analysis by quantitative real-time PCR}

Total RNA was isolated using TRIzol (Invitrogen) and chloroform (Sigma) from N39 cells and ground brain tissues. For qRT-PCR analysis, $3 \mu \mathrm{g}$ of total RNA from each sample was reverse-transcribed using a Reverse Transcription System (Promega). Synthesized cDNA was diluted 1:5 with water, and $2 \mu \mathrm{l}$ was used as a template for qRT-PCR. Primers were designed as follows: Ins1 Forward, 5' -AGAGACCATCAGCAAGCAGGTCA3'; Ins1 Reverse, 5'-TACCAGGTGGGGACCACAAA GA-3'; Ins2 Forward, 5'-GTGACCTTCAGACCTTGG CACTG-3'; Ins2 Reverse, 5'-AGGCTGGGTAGTGGT GGGTCTAG-3'; NeuroD1 Forward, 5'-TGACCTTTC CCATGCTGAAT-3'; NeuroD1 Reverse, 5'-AAGTGC TAAGGCAACGCAAT-3'; GAPDH Forward, 5'-GTC AATGAAGGGGTCGTTGATGG-3'; and GAPDH Reverse, 5'-TCGTCCCGTAGACAAAATGGTGA-3'. qRT-PCR was performed according to the SYBR Green protocol (SYBR Premix Ex Taq, TaKaRa) in a Bio-Rad CFX-96 machine. Annealing and extension were done at $63{ }^{\circ} \mathrm{C}$.

\section{Enzyme-linked immunosorbent assay}

Culture medium from Wnt3a-treated N39 cells was collected and filtered with a $0.22 \mu \mathrm{m}$ syringe filter. Vivaspin 2 (2000 MWCO Hydrosart; Sartorius) was used to concentrate $3 \mathrm{~mL}$ of medium to $35 \mu \mathrm{L}$. Insulin concentrations in concentrated media were measured by using an ELISA kit, which detects only mature insulin, purchased from ALPCO Diagnostics.

\section{Immunoblot analysis}

N39 cells were plated at a density of $1.0 \times 10^{5} / \mathrm{mL}$ in 6-well plates. After appropriate treatments, cells were washed with ice-cold PBS and harvested in lysis buffer (50 mM Tris- $\mathrm{HCl}, \mathrm{pH} 7.4,250 \mathrm{mM}$ sucrose, $5 \mathrm{mM}$ sodium pyrophosphate, $1 \mathrm{mM}$ EDTA, $1 \mathrm{mM}$ EGTA, $1 \%$ Triton X-100, $0.1 \mathrm{mM}$ benzamidine, $10 \mu \mathrm{g} / \mathrm{mL}$ leupeptin, $1 \mathrm{mM}$ DTT, $0.5 \mathrm{mM}$ PMSF, $50 \mathrm{mM}$ NaF, $1 \mathrm{X}$ protease inhibitor cocktail (Calbiochem), 1X phosphatase inhibitor cocktail (Sigma). Protein was extracted from hypothalamic tissues with the same lysis buffer. Lysates $(20 \mu \mathrm{g}$ total protein) were separated on $10 \%$ SDS-polyacrylamide gels and blotted onto polyvinylidene difluoride membranes for $40 \mathrm{~min}$ at $20 \mathrm{~V}$ in transfer buffer containing $25 \mathrm{mM}$ Tris base and $192 \mathrm{mM}$ glycine. The membranes were blocked with $5 \%$ skim milk for $3 \mathrm{~h}$ and then incubated with primary antibodies against non-phospho $\beta$-catenin (1:3000; Cell Signaling), total $\beta$-catenin (1:3000; Cell Signaling), NeuroD1 (1:3000; AbCam), or glyceraldehyde-3-phosphate dehydrogenase (GAPDH) (1:5000; Cell Signaling) at $4{ }^{\circ} \mathrm{C}$ overnight. After three washes with Tris-buffered saline with $0.1 \%$ of Tween 20 (TBST), the membranes were incubated with horseradish peroxidase-linked secondary antibody and washed with TBST three times and visualized by SuperSignal West Pico Chemiluminescent Substrate (Thermo) according to the manufacturer's procedure. The intensity of bands was quantified using NIH ImageJ analysis software.

\section{Immunofluorescence analysis}

N39 cells were seeded on poly-L-lysine-coated coverslips. After treatment with Wnt3a for $24 \mathrm{~h}$, cells were washed with PBS, fixed with $4 \%$ paraformaldehyde and permeabilized in $0.2 \%$ Triton X-100, $0.1 \mathrm{M}$ glycine. The cells were then washed with PBS, blocked with BSA containing antibody diluent (Invitrogen) at room temperature (RT) and incubated with antibodies against proinsulin (1:50; R\&D Systems), non-phospho $\beta$-catenin (1:500; Cell Signaling), and NeuroD1 (1:200; Santa Cruz) at $4{ }^{\circ} \mathrm{C}$. Coverslips were incubated with secondary antibodies for $2 \mathrm{~h}$ at RT, and Hoechst 33342 (Invitrogen) was used for nuclear staining for $10 \mathrm{~min}$ at RT. ProLong Diamond Antifade Mountant (Invitrogen) was used for mounting coverslips. Each slide was analyzed with an LSM700 confocal microscope (Carl Zeiss). Images were analyzed with ZEN2012 software (Carl Zeiss).

\section{Preperation of lentiviral shRNAs}

Five TRC Lentiviral Non-targeting shRNAs control (\#RHS6848) and mouse NeuroD1 shRNAs (81773-81777, Dharmacon) were cloned into the pLKO.1 lentiviral vector. The pMD2.G and psPAX2 vectors were used as an envelope and packaging vector, respectively, to produce lentivirus in the Lenti-X $293 \mathrm{~T}$ cell line (Clontech). Transient transfections were performed with TurboFect Transfection Reagent (Thermo) according to the manufacturer's protocol. Cell supernatants containing virus were collected $72 \mathrm{~h}$ post-transfection and filtered through $0.45 \mu \mathrm{m}$ syringe filters. Lentiviral vectors were concentrated by 
ultracentrifugation at $40,000 \times g$ for $90 \mathrm{~min}$ at $4{ }^{\circ} \mathrm{C}$. Viral pellets were suspended in PBS.

\section{Statistical analysis}

Data were analyzed with GraphPad Prism software (GraphPad Software). Statistical analysis was performed using unpaired $t$-test.

\section{Additional file}

\section{Additional file 1: Supplemental Figure S1. Wnt3a induces NeoruD1} prior to upregulation of Ins2. N39 cells were treated with vehicle (PBS) or Wnt3a (25 or $100 \mathrm{ng} / \mathrm{mL}$ ) for 1.5, 3 and 4.5h, and the levels of NeoruD1 mRNA (A) and Ins2 mRNA (B) were measured by qRT-PCR and normalized to the levels of GAPDH mRNA ( $n=9$ ). Data are means + SEM. ${ }^{*} p<0.05$, ** $p<0.01,{ }^{* * *} p<0.001$ compared with vehicle control at each time point. (JPG $976 \mathrm{~kb})$

\section{Abbreviations}

AgRP: agouti-related peptide; BDI: brain-derived insulin; DIO: diet-induced obese; Fz: frizzled; GSK3: glycogen synthase kinase 3; IR: insulin receptor; LRP: low density lipoprotein receptor-related protein; N39 cell: mouse hypothalamic neuronal cell; NeuroD1: neurogenic differentiation 1; NIRKO: neuron-specific insulin receptor knockout; ob/ob: leptin-deficient; POMC: pro-opiomelanocortin; SF1: steroidogenic factor 1; TCF: T-cell factor.

\section{Competing interests}

The authors declare that they have no conflict of interests.

\section{Authors' contributions}

$J L$ and EKK conceived and designed the study, interpreted the results, and wrote the manuscript. JL and KK planned and performed experiments and analyzed the results. SWY discussed the study and wrote the manuscript. All authors read and approved the final manuscript.

\section{Acknowledgements}

This work was supported by the National Research Foundation of South Korea (Grant No. 2013M3C7A1056099 and 2012M3A9C6049935) and the DGIST R\&D Program of the Ministry of Science, Information and Communication Technology, and Future Planning of South Korea (Grant No. 15-BD-0402).

Received: 10 December 2015 Accepted: 26 February 2016 Published online: 08 March 2016

\section{References}

1. Schechter R, Whitmire J, Holtzclaw L, George M, Harlow R, Devaskar SU. Developmental regulation of insulin in the mammalian central nervous system. Brain Res. 1992;582(1):27-37.

2. Bruning JC, Gautam D, Burks DJ, Gillette J, Schubert M, Orban PC, et al. Role of brain insulin receptor in control of body weight and reproduction. Science. 2000;289(5487):2122-5.

3. Woods SC, Seeley RJ, Baskin DG, Schwartz MW. Insulin and the blood-brain barrier. Curr Pharm Des. 2003;9(10):795-800.

4. Fisher SJ, Bruning JC, Lannon S, Kahn CR. Insulin signaling in the central nervous system is critical for the normal sympathoadrenal response to hypoglycemia. Diabetes. 2005;54(5):1447-51.

5. Ott ASR, van Harskamp F, Pols HA, Hofman A, Breteler MM. Diabetes mellitus and the risk of dementia: the Rotterdam study. Neurology. 1999:53(9):1937-42.

6. Steen E, Terry BM, Rivera EJ, Cannon JL, Neely TR, Tavares R, et al. Impaired insulin and insulin-like growth factor expression and signaling mechanisms in Alzheimer's disease-is this type 3 diabetes? J Alzheimers Dis. 2005;7(1):63-80.

7. Schubert M, Gautam D, Surjo D, Ueki K, Baudler S, Schubert D, et al. Role for neuronal insulin resistance in neurodegenerative diseases. Proc Natl Acad Sci U S A. 2004;101(9):3100-5. doi:10.1073/pnas.0308724101.

8. Cohen E, Dillin A. The insulin paradox: aging, proteotoxicity and neurodegeneration. Nat Rev Neurosci. 2008;9(10):759-67. doi:10.1038/nrn2474.
9. Moloney AM, Griffin RJ, Timmons S, O'Connor R, Ravid R, O'Neill C. Defects in IGF-1 receptor, insulin receptor and IRS-1/2 in Alzheimer's disease indicate possible resistance to IGF-1 and insulin signalling. Neurobiol Aging. 2010;31(2):224-43. doi:10.1016/j.neurobiolaging.2008.04.002

10. Liu Y, Liu F, Grundke-lqbal I, lqbal K, Gong CX. Deficient brain insulin signalling pathway in Alzheimer's disease and diabetes. J Pathol. 2011;225(1):54-62. doi:10.1002/path.2912.

11. Margolis RU, Altszuler N. Insulin in the cerebrospinal fluid. Nature. 1967:215(5108):1375-6.

12. Banks WA, Jaspan JB, Huang W, Kastin AJ. Transport of insulin across the blood-brain barrier: saturability at euglycemic doses of insulin. Peptides. 1997;18(9):1423-9.

13. Havrankova J, Roth J, Brownstein M. Insulin receptors are widely distributed in the central nervous system of the rat. Nature. 1978;272(5656):827-9.

14. Madadi G, Dalvi PS, Belsham DD. Regulation of brain insulin mRNA by glucose and glucagon-like peptide 1. Biochem Biophys Res Commun. 2008;376(4):694-9. doi:10.1016/j.bbrc.2008.09.054.

15. Mehran AE, Templeman NM, Brigidi GS, Lim GE, Chu KY, Hu X, et al. Hyperinsulinemia drives diet-induced obesity independently of brain insulin production. Cell Metab. 2012;16(6):723-37. doi:10.1016/j.cmet.2012.10.019.

16. Shiao MS, Liao BY, Long M, Yu HT. Adaptive evolution of the insulin two-gene system in mouse. Genetics. 2008;178(3):1683-91. doi:10.1534/genetics.108.087023.

17. Young 3rd WS. Periventricular hypothalamic cells in the rat brain contain insulin mRNA. Neuropeptides. 1986;8(2):93-7.

18. Devaskar SU, Singh BS, Carnaghi LR, Rajakumar PA, Giddings SJ. Insulin II gene expression in rat central nervous system. Regul Pept. 1993;48(1-2):55-63.

19. Devaskar SU, Giddings SJ, Rajakumar PA, Carnaghi LR, Menon RK, Zahm DS. Insulin gene expression and insulin synthesis in mammalian neuronal cells. J Biol Chem. 1994;269(11):8445-54.

20. Singh BS, Rajakumar PA, Eves EM, Rosner MR, Wainer BH, Devaskar SU. Insulin gene expression in immortalized rat hippocampal and pheochromocytoma-12 cell lines. Regul Pept. 1997;69(1):7-14.

21. Hrytsenko O, Wright Jr JR, Morrison CM, Pohajdak B. Insulin expression in the brain and pituitary cells of tilapia (Oreochromis niloticus). Brain Res. 2007;1135(1):31-40. doi:10.1016/j.brainres.2006.12.009.

22. Gerozissis K. Brain insulin, energy and glucose homeostasis; genes, environment and metabolic pathologies. Eur J Pharmacol. 2008;585(1):38-49. doi:10.1016/j.ejphar.2008.01.050

23. Molnar G, Farago N, Kocsis AK, Rozsa M, Lovas S, Boldog E, et al. GABAergic neurogliaform cells represent local sources of insulin in the cerebral cortex. J Neurosci. 2014;34(4):1133-7. doi:10.1523/JNEUROSCl.4082-13.2014.

24. Dorn A, Rinne A, Bernstein HG, Hahn HJ, Ziegler M. Insulin and C-peptide in human brain neurons (insulin/C-peptide/brain peptides/ immunohistochemistry/radioimmunoassay). J Hirnforsch. 1983;24(5):495-9.

25. Frolich L, Blum-Degen D, Bernstein HG, Engelsberger S, Humrich J, Laufer S, et al. Brain insulin and insulin receptors in aging and sporadic Alzheimer's disease. J Neural Transm. 1998:105(4-5):423-38.

26. Lee SM, Tole S, Grove E, McMahon AP. A local Wnt-3a signal is required for development of the mammalian hippocampus. Development. 2000;127(3):457-67.

27. Galceran J, Miyashita-Lin EM, Devaney E, Rubenstein JL, Grosschedl R. Hippocampus development and generation of dentate gyrus granule cells is regulated by LEF1. Development. 2000:127(3):469-82.

28. Zhou CJ, Zhao C, Pleasure SJ. Wnt signaling mutants have decreased dentate granule cell production and radial glial scaffolding abnormalities. J Neurosci. 2004;24(1):121-6. doi:10.1523/JNEUROSCI.4071-03.2004.

29. Logan CY, Nusse R. The Wnt signaling pathway in development and disease. Annu Rev Cell Dev Biol. 2004;20:781-810. doi:10.1146/annurev. cellbio.20.010403.113126.

30. Sander M, German MS. The beta cell transcription factors and development of the pancreas. J Mol Med (Berl). 1997;75(5):327-40.

31. Heller RS, Klein T, Ling Z, Heimberg H, Katoh M, Madsen OD, et al. Expression of Wnt, Frizzled, sFRP, and DKK genes in adult human pancreas. Gene Expr. 2003:11(3-4):141-7.

32. Fujino T, Asaba H, Kang MJ, Ikeda Y, Sone H, Takada S, et al. Low-density lipoprotein receptor-related protein 5 (LRP5) is essential for normal cholesterol metabolism and glucose-induced insulin secretion. Proc Natl Acad Sci U S A. 2003;100(1):229-34. doi:10.1073/pnas.0133792100.

33. Papadopoulou S, Edlund $\mathrm{H}$. Attenuated Wnt signaling perturbs pancreatic growth but not pancreatic function. Diabetes. 2005;54(10):2844-51. 
34. Wells JM, Esni F, Boivin GP, Aronow BJ, Stuart W, Combs C, et al. Wnt/ $\beta$ catenin signaling is required for development of the exocrine pancreas. BMC Dev Biol. 2007;7(1):4.

35. Kuwabara $T$, Kagalwala MN, Onuma $Y$, Ito $Y$, Warashina $M$, Terashima $K$, et al. Insulin biosynthesis in neuronal progenitors derived from adult hippocampus and the olfactory bulb. EMBO Mol Med. 2011;3(12):742-54 doi:10.1002/emmm.201100177.

36. Schinner S, Ulgen F, Papewalis C, Schott M, Woelk A, Vidal-Puig A, et al. Regulation of insulin secretion, glucokinase gene transcription and beta cell proliferation by adipocyte-derived Wnt signalling molecules. Diabetologia. 2008:51(1):147-54. doi:10.1007/s00125-007-0848-0.

37. Patel S, Doble B, Woodgett JR. Glycogen synthase kinase-3 in insulin and Wnt signalling: a double-edged sword? Biochem Soc Trans. 2004;32(Pt 5):803-8. doi:10.1042/BST0320803.

38. Welters HJ, Kulkarni RN. Wnt signaling: relevance to beta-cell biology and diabetes. Trends Endocrinol Metab. 2008;19(10):349-55. doi:10.1016/j.tem.2008.08.004

39. Rulifson IC, Karnik SK, Heiser PW, ten Berge D, Chen H, Gu X, et al. Wnt signaling regulates pancreatic beta cell proliferation. Proc Natl Acad Sci U S A. 2007;104(15):6247-52. doi:10.1073/pnas.0701509104.

40. Maretto S, Cordenonsi M, Dupont S, Braghetta P, Broccoli V, Hassan AB, et al. Mapping Wnt/beta-catenin signaling during mouse development and in colorectal tumors. Proc Natl Acad Sci U S A. 2003;100(6):3299-304. doi:10.1073/pnas.0434590100

41. Wang $X$, Kopinke D, Lin J, McPherson AD, Duncan RN, Otsuna H, et al. Wnt signaling regulates postembryonic hypothalamic progenitor differentiation. Dev Cell. 2012;23(3):624-36. doi:10.1016/j.devcel.2012.07.012.

42. Kokoeva MV, Yin H, Flier JS. Neurogenesis in the hypothalamus of adult mice: potential role in energy balance. Science. 2005;310(5748):679-83. doi:10.1126/science.1115360.

43. Pierce AA, Xu AW. De novo neurogenesis in adult hypothalamus as a compensatory mechanism to regulate energy balance. J Neurosci. 2010;30(2):723-30. doi:10.1523/JNEUROSCI.2479-09.2010.

44. Benzler J, Ganjam GK, Kruger M, Pinkenburg O, Kutschke M, Stohr S, et al. Hypothalamic glycogen synthase kinase 3 beta has a central role in the regulation of food intake and glucose metabolism. Biochem J. 2012:447(1):175-84. doi:10.1042/BJ20120834.

45. Benzler J, Andrews ZB, Pracht C, Stohr S, Shepherd PR, Grattan DR, et al. Hypothalamic WNT signalling is impaired during obesity and reinstated by leptin treatment in male mice. Endocrinology. 2013;154(12):4737-45. doi:10.1210/en.2013-1746.

46. Fernandez AM, Torres-Aleman I. The many faces of insulin-like peptide signalling in the brain. Nat Rev Neurosci. 2012;13(4):225-39. doi:10.1038/nrn3209.

47. Gui S, Yuan G, Wang L, Zhou L, Xue Y, Yu Y, et al. Wnt3a regulates proliferation, apoptosis and function of pancreatic NIT-1 beta cells via activation of IRS2/PI3K signaling. J Cell Biochem. 2013;114(7):1488-97. doi:10.1002/jcb.24490.

48. Staal FJ, Noort Mv M, Strous GJ, Clevers HC. Wnt signals are transmitted through N-terminally dephosphorylated beta-catenin. EMBO Rep. 2002;3(1):63-8. doi:10.1093/embo-reports/kvf002

49. Li VS, Ng SS, Boersema PJ, Low TY, Karthaus WR, Gerlach JP, et al. Wnt signaling through inhibition of beta-catenin degradation in an intact Axin1 complex. Cell. 2012;149(6):1245-56. doi:10.1016/j.cell.2012.05.002.

50. Meijer L, Skaltsounis AL, Magiatis P, Polychronopoulos P, Knockaert M, Leost $M$, et al. GSK-3-selective inhibitors derived from Tyrian purple indirubins. Chem Biol. 2003;10(12):1255-66.

51. Sato N, Meijer L, Skaltsounis L, Greengard P, Brivanlou AH. Maintenance of pluripotency in human and mouse embryonic stem cells through activation of Wnt signaling by a pharmacological GSK-3-specific inhibitor. Nat Med. 2004;10(1):55-63. doi:10.1038/nm979.

52. Sharma A, Moore M, Marcora E, Lee JE, Qiu Y, Samaras S, et al. The NeuroD1/BETA2 sequences essential for insulin gene transcription colocalize with those necessary for neurogenesis and p300/CREB binding protein binding. Mol Cell Biol. 1999;19(1):704-13.

53. Obici S, Zhang BB, Karkanias G, Rossetti L. Hypothalamic insulin signaling is required for inhibition of glucose production. Nat Med. 2002;8(12):1376-82. doi:10.1038/nm798.

54. Porte Jr D, Baskin DG, Schwartz MW. Insulin signaling in the central nervous system: a critical role in metabolic homeostasis and disease from C. elegans to humans. Diabetes. 2005;54(5):1264-76.
55. Kuwabara T, Hsieh J, Muotri A, Yeo G, Warashina M, Lie DC, et al. Wnt-mediated activation of NeuroD1 and retro-elements during adult neurogenesis. Nat Neurosci. 2009;12(9):1097-105. doi:10.1038/nn.2360.

56. Cross DA, Alessi DR, Cohen $P$, Andjelkovich $M$, Hemmings BA. Inhibition of glycogen synthase kinase-3 by insulin mediated by protein kinase B. Nature. 1995;378(6559):785-9. doi:10.1038/378785a0.

57. Srivastava AK, Pandey SK. Potential mechanism(s) involved in the regulation of glycogen synthesis by insulin. Mol Cell Biochem. 1998;182(1-2):135-41.

58. Lee JE. Basic helix-loop-helix genes in neural development. Curr Opin Neurobiol. 1997;7(1):13-20.

59. Crews ST, Fan CM. Remembrance of things PAS: regulation of development by bHLH-PAS proteins. Curr Opin Genet Dev. 1999;9(5):580-7.

60. Mutoh H, Fung BP, Naya FJ, Tsai MJ, Nishitani J, Leiter AB. The basic helixloop-helix transcription factor BETA2/NeuroD is expressed in mammalian enteroendocrine cells and activates secretin gene expression. Proc Natl Acad Sci U S A. 1997:94(8):3560-4.

61. Khoo S, Griffen SC, Xia Y, Baer RJ, German MS, Cobb MH. Regulation of insulin gene transcription by ERK1 and ERK2 in pancreatic beta cells. J Biol Chem. 2003;278(35):32969-77. doi:10.1074/jbc.M301198200.

62. Petersen HV, Jensen JN, Stein R, Serup P. Glucose induced MAPK signalling influences NeuroD1-mediated activation and nuclear localization. FEBS Lett. 2002:528(1-3):241-5.

63. Konner AC, Janoschek R, Plum L, Jordan SD, Rother E, Ma X, et al. Insulin action in AgRP-expressing neurons is required for suppression of hepatic glucose production. Cell Metab. 2007;5(6):438-49. doi:10.1016/j.cmet.2007.05.004.

64. Klockener T, Hess S, Belgardt BF, Paeger L, Verhagen LA, Husch A, et al. High-fat feeding promotes obesity via insulin receptor/PI3K-dependent inhibition of SF-1 VMH neurons. Nat Neurosci. 2011;14(7):911-8. doi:10.1038/nn.2847.

65. Kim EK, Miller I, Aja S, Landree LE, Pinn M, McFadden J, et al. C75, a fatty acid synthase inhibitor, reduces food intake via hypothalamic AMP-activated protein kinase. J Biol Chem. 2004;279(19):19970-6. doi:10.1074/jbc.M402165200.

\section{Submit your next manuscript to BioMed Central and we will help you at every step:}

- We accept pre-submission inquiries

- Our selector tool helps you to find the most relevant journal

- We provide round the clock customer support

- Convenient online submission

- Thorough peer review

- Inclusion in PubMed and all major indexing services

- Maximum visibility for your research

Submit your manuscript at www.biomedcentral.com/submit 